
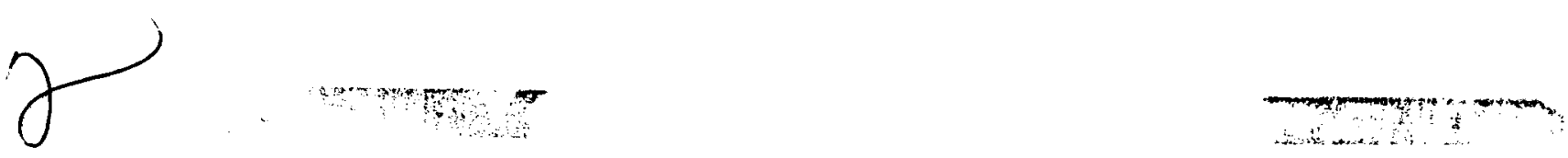

UCID- 19059

\title{
A Sedimentation Plan to Assess the Impact \\ of Geothermal Activities to the Aquatic \\ Ecosystem in The Geysers Calistoga KGRA

\author{
Ecosystem in The Geysers Calistoga KGRA
}

Robert R.: Irel and

\section{MASTER}

May 19, 1981

This is an informal report intended primarily for internal or limited external distribution. The opinions and conclusions stated are those of the author and may or may not be those of the Laboratory.

Work performed under the auspices of the U.S. Department of Energy by the Lawrence Livermore Laboratory under Contract W-7405-Eng-48.

\section{UNCLASSIFIED}

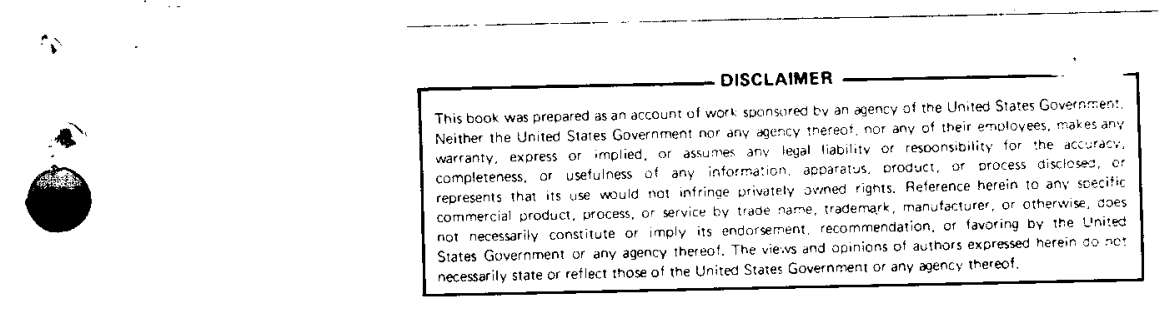

DISTRIBUTION OF THIS DOCUMENT IS UNLIMITED 


\section{DISCLAIMER}

This report was prepared as an account of work sponsored by an agency of the United States Government. Neither the United States Government nor any agency Thereof, nor any of their employees, makes any warranty, express or implied, or assumes any legal liability or responsibility for the accuracy, completeness, or usefulness of any information, apparatus, product, or process disclosed, or represents that its use would not infringe privately owned rights. Reference herein to any specific commercial product, process, or service by trade name, trademark, manufacturer, or otherwise does not necessarily constitute or imply its endorsement, recommendation, or favoring by the United States Government or any agency thereof. The views and opinions of authors expressed herein do not necessarily state or reflect those of the United States Government or any agency thereof. 


\section{DISCLAIMER}

Portions of this document may be illegible in electronic image products. Images are produced from the best available original document. 


\section{A Sedimentation Plan to Assess the Impact of Geothermal Activities to the Aquatic Ecosystem in The Geysers Calistoga KGRA}

Robert R. Ireland

May 19, 1981 


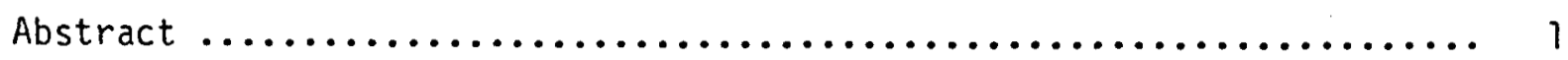

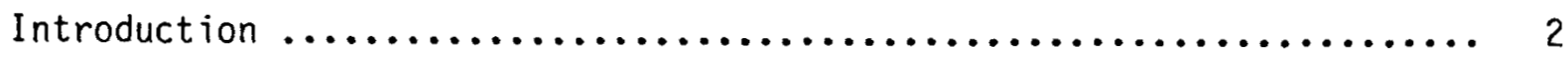

Field Sample Collection $\ldots \ldots \ldots \ldots \ldots \ldots \ldots \ldots \ldots \ldots \ldots \ldots \ldots \ldots \ldots$

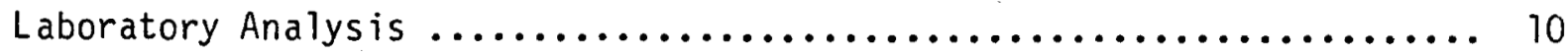

Data Storage and Analysis ............................... 11

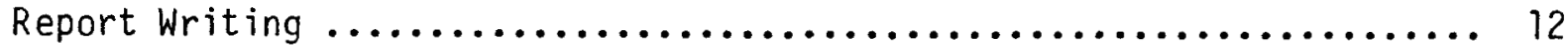

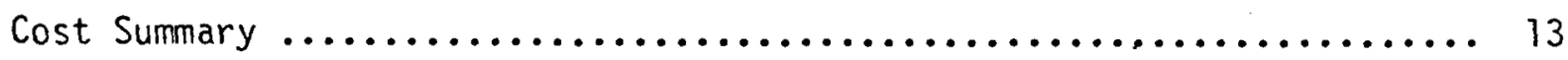

Appendix 1: Background of the KGRA-ARM Task Force $\ldots \ldots \ldots \ldots \ldots \ldots$

Appendix 2: Sediment Sampling Sites and Rationale

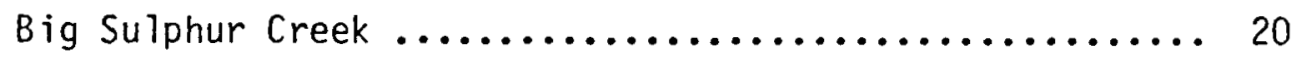

Uppper Putah Creek ......................... 25

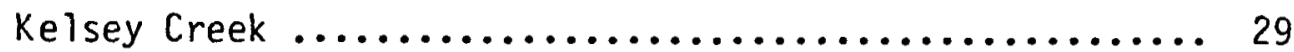

Appendix 3: Directions for Testing Geysers Sediment Samples ....... 32

Appendix 4: Examples of Computer Generated Graphic Displays

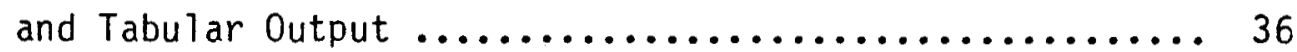




\section{Abstract}

The prevention of sedimentation or siltation in aquatic ecosystems is always a key environmental issue in the development and operation of power plant units. This report describes a field program which will assess the amount of sedimentation in the streams and tributaries of The Geysers-Calistoga Known Geothermal Resource Area (KGRA) due to development-related or other site-specific activities. This sediment plan is one part of a four part venture - the others are water quality, benthic invertebrates and fisheries studies - initiated by the California Energy Commission and involving numerous California organizations. Included in this report are the cost breakdowns for each phase, maps and rationale of the sampling sites, the methodology for the laboratory sample processing, and examples of the type of graphic and tabular output expected.

*

Work performed under the auspices of the U.S. Department of Energy by the Lawrence Livermore Laboratory under contract No. W-7405-ENG-48. 


\section{Introduction}

Since its first meeting in August, 1979, a group which would soon cal1 itself the KGRA-ARM Task Force has been moving towards the implementation of a comprehensive, cooperative program to evaluate and monitor the chronic and cumulative effects of geothermal development in The Geysers-Calistoga KGRA (for more background on the Task Force, please see Appendix 1). One of the initial decisions of the Task Force was to establish four technical subcommittees to develop detailed programs in four disciplines: water quality, fisheries, benthic invertebrates, and sedimentation.

Sedimentation was chosen as one of the four areas since it is generally agreed that erosion and its uitimate impact upon the aquatic ecosystem is one of the key issues related to development of geothermal energy. Erosion, whether initiated by drilling, road building or natural causes, leads to an increase in the amount of the silt and sediment in the streambed. From a physical standpoint, siltation may impede the reproduction, development and emergence of the aquatic invertebrates essential to a healthy stream. Furthermore, siltation is known to be deleterious to fish spawning success by filling in the interstices of the gravel beds needed for egg development. From a chemical standpoint, most erosion activities add organic matter to the water thereby increasing the oxygen demand. Drastic siltation could even ultimately lead to changes in sediment redox potentials with resultant resolubilization of inertly bound elements - a notable concern in an area such as The Geysers where high natural sediment mercury concentrations are present.

By virtue of the fact that the author was currently conducting an aquatic ecology program in The Geysers focusing upon sediment - water interactions, he was chosen as the committee chairman for the sediment group. This report represents the summation of the sediment subcommittee's recommended program. 
The penultimate meeting of our committee was held December 9, 1980 at LLNL. The purpose was to finalize the strategies, costs, goals and implementation of this segment of the overall program. Those in attendance included: Robert Ireland of LLNL, Gerald Boles of the Department of Water Resources (DWR), Robert Karfoil, Dave Longanecker and Lucy McMillan of Pacific Gas and Electric (PG\&E), and Lloyd Dillion and Marco Farro of the California Energy Commission (CEC).

Several considerations were inherent in the direction of the sediment plan. First, we wished to orient our data gathering in order to complement the other committees' phases towards meeting their overall goals. This would undoubtedly assist in the integration and interpretation of the data. Secondly, we decided that the data should be able to stand by itself in providing a quantification of the physical impact of development-related siltation. If we could recognize and achieve those two goals, then the data would be that much more amenable for use in the attainment of the Task Force's overall objectives, especially including the assessment of current control measures and the recommendation of any further mitigation procedures.

The rest of this report is broken down into four parts. In each section, the costs and methodology are summarized. The four parts to be discussed in order are:

1. Field sample collection

2. Laboratory analysis

3. Data storage and analysis

4. Report writing 
Comparative cost analyses revealed that DWR would be more cost-effective for actual sample collection. Numerous factors were considered in this decision including whether personnel were in-house professionals, union members desirous of overtime, as well as general overhead multipliers, etc. The breakdown of cost to DWR is found in Table 1.

Table 1.

\section{DWR Estimate of Field Sample Collection}

A. Sample Collection

$\begin{array}{ll}15 \text { days/run (run }=41 \text { sites) } & x \\ 8 \text { hours/day } & x \\ 2 \text { runs/year } & x \\ 3 \text { peop le/run } & x \\ \text { Wages and overhead factors } & =\$ 14,440\end{array}$

B. Expenses

11 days/run

$x$

2 runs/year

$x$

3 people/run

$x$

$\$ 50 /$ day/person

$=\$ 3,300$

C. Equipment

$=\$ 1,000$

$\$ 18,740$

D. Contingency at $10 \%$

1,874

Total (1st year)

$\$ 20,614$ 
Forty one (41) sites were chosen within the three drainages of The Geysers KGRA: Big Sulphur Creek, Upper Putah Creek and Kelsey Creek. Costs were not broken down into drainages since some overlap may occur within the same day. Allowances were made considering travel time between sites and the total length of time per run. The location of the forty one sites and the rationale for selecting them are found in Appendix 2.

Duties performed at the collection site will include: 1) actual removal and packaging of the sediment and water, 2) photographs of the stream for visual documentation of surface fines and 3) measurement of certain basic water quality parameters. These will be discussed in order.

The exact spot where gravel will be sampled will be chosen after careful onsite inspection. Usually this spot will be the gravel riffle at the end of a pool because this area will remain somewhat uniform over time, not be subject to excessive gouging as in the pool, and would be the preferred location for the fish spawning (Figure 1).

The main tool to be used will be the McNeil gravel sampler (see Figure 2). As can be seen from the diagram, the sampler is roughly cylindrical with an internal shelf. One works the sampler into the gravel approximately six inches deep as determined by the weld on the inside. This confines a unit volume, approximately 2.7 liters, of rock, sediment and water. Larger material is extracted by hand and saved by placing it in the internal shelf. This continues until the nubs at the bottom are uncovered. A stainless steel plunger with a compressible 0-ring (figure 3 ) is then forced to the bottom and tightened to prevent water leakage. This allows one to quantitively remove all the water and silt (fines) remaining within the cylinder. All the gravel, sediment and water are appropriately packaged and labeled for transport back to the lab. 
This sampling procedure is repeated five times in the same gravel riff. In the laboratory, the rocks, gravel and water solids will be recombined for each replicate. This mixture will then be processed through a series of six sieves with mesh sizes from $1.5 \mathrm{~mm}$ to $0.074 \mathrm{~mm}$.

This is mentioned in this section rather than the next because it helps explain cost factors. Even though sites have been chosen with an eye for accessibility, often a laborious trek out of a steep canyon are unavoidable. It has been the experience of PG\&E that a minimum of three people are required to carry the gravel and water back to the vehicle. Moreover, having the proper initial manpower allows the personnel to remove all of the sample thereby saving laboratory and analysis time (and money) which would increase if subsequent subsampling were necessary.

Two other duties were also mentioned as part of the sediment collection schema: photographs and water parameters. Most of the time these phases will be conducted by menbers of other groups, respectively, the benthic invertebrate team and the water quality team, inasmuch as most of the sampling locations are multiple sites. Most committee members agree that true cost efficacy would result from a cooroinated sampling effort of all teams at the same site at the same time. The program manager will be responsible for coordinating this.

In the case of an isolated sediment site, photographs will still be taken. Also, a mininum of water parameters should be noted such as flow, temperature, $\mathrm{pH}$, dissolved oxygen, conductivity and turbidity. The equipment required to perform such tasks should not significantly add to the burden of the three-person team. 

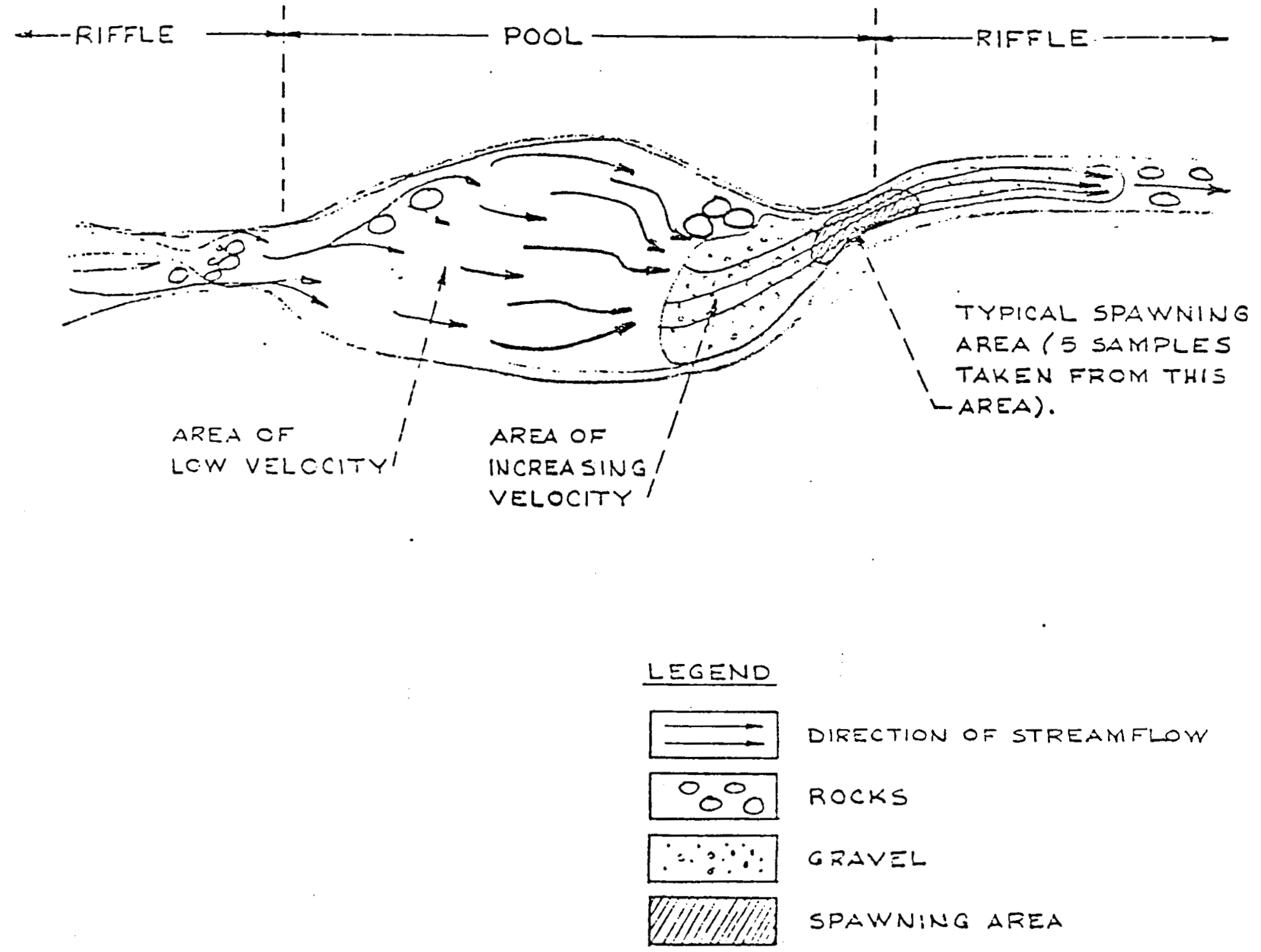

Figure 1. Plan view of typical spawning area (Reprinted from PG\&E Report 420-79.41, 1979) 

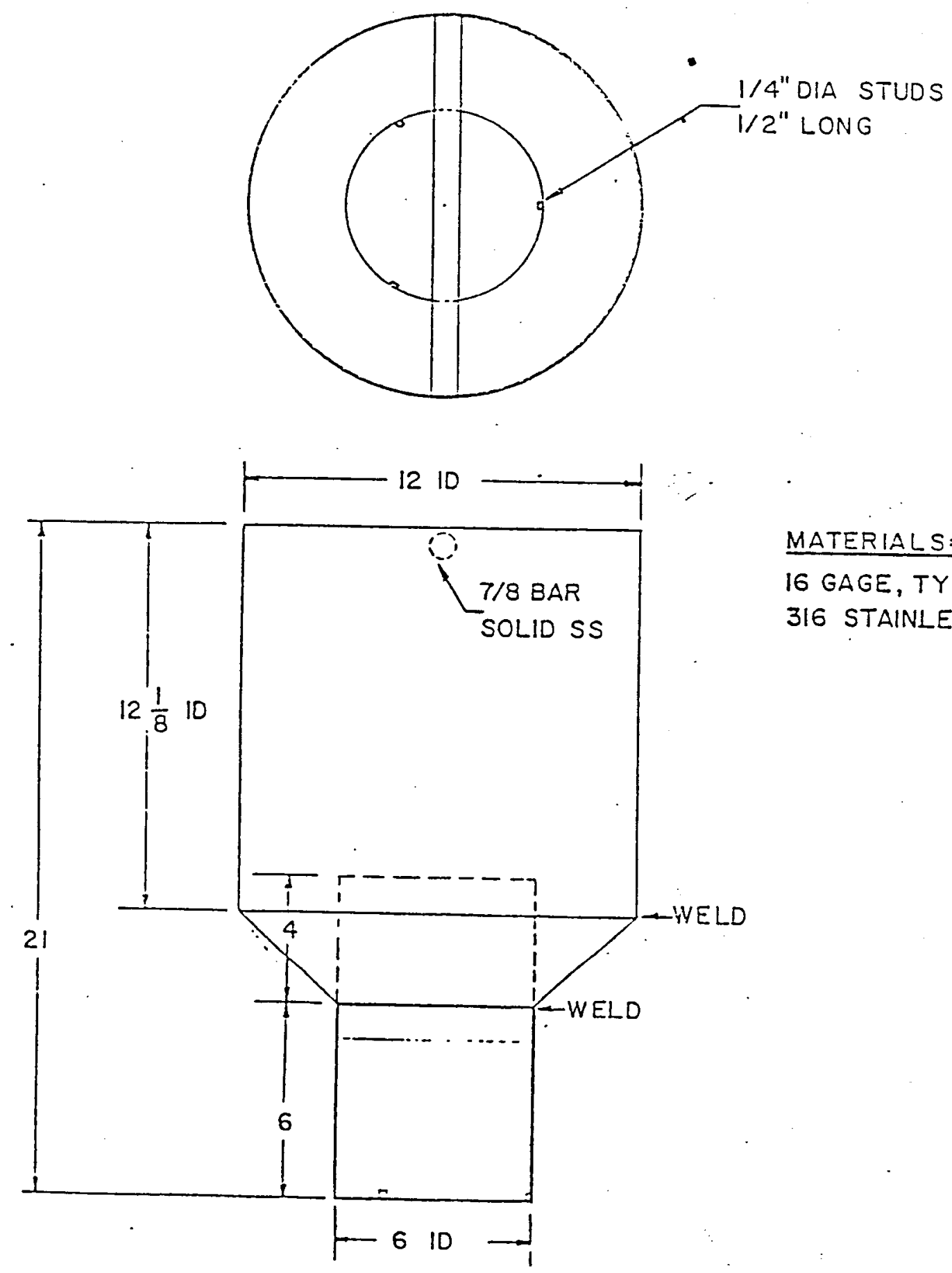

MATERIALS: 16 GAGE, TYPE 316 STAINLESS

Figure 2. Gravel sampler (Reprinted from PG\&E Report 420-79.41, 1979) 


\section{SEALING FLUNGER INSERT FOR GRAVEL SAMPLER}
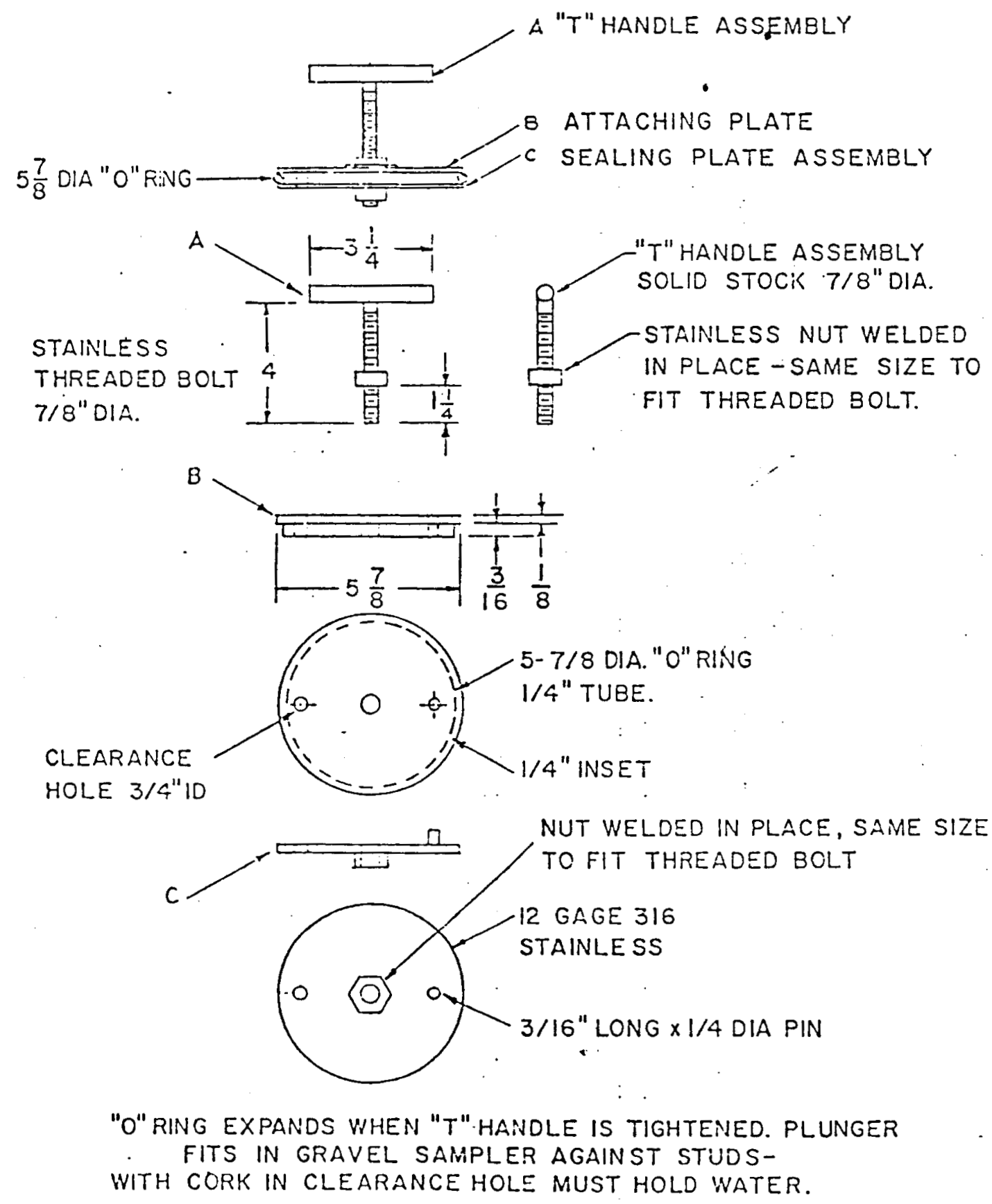

Figure 3. Sealing plunger insert for gravel sampler

(Reprinted from PG\&E Report 420-79.41, 1979) 
It was apparent that PG\&E was the most feasible choice to handle the laboratory analysis of the sediment samples after comparisons of manpower, expertise, and equipment and other factors.

PG\&E estimated their laboratory costs to run $\$ 17,678$ for one year. This accounts for analyses of two sampling runs of forty-one sites each run with five replicates at each stations. DWR is responsible for ensuring delivery of the samples to PG\&E. In the lab, samples will be recombined, weighed and sieved as mentioned previously.

Appendix 3 contains the full directions for the laboratory procedure. Also included is the raw data sheet upon which the proper weights, sizes and other data are hand recorded. 
PG\&E was easily the most practical choice to perform this segment of the sediment because of their expertise and computer facilities with existing software for graphical and statistical displays.

The cost was estimated to be $\$ 1,000$ for one year. Most of this money would be used for transferring the handwritten data onto punched computer cards. An additional factor would be the relatively small cost of the computer printouts.

As mentioned previously, the objectives of the sediment plan are to 1) determine whether geothermal development activities are increasing erosional processes which ultimately add to increases in streambed sedimentation and 2) to provide data for the other phases of the Task Force which would serve to enhance their data or interpretation of that data. Towards this end, the capabilities of the existing PG\&E computational programs are excellent. Their graphical displays of digested data and statistical tables will certainly facilitate the above goals as well as aid in the writing the final report.

Appendix 4 contains numerous examples of the type of graphic and tabular output which PG\&E has aiready produced with sediment data. 


\section{Report Writing}

The writing of the sediment report was mutually decided to be a small group effort consisting of LLNL, PG\&E and DWR. This trio will convene to collectively interpret the data, summarize the trends and recommend what future courses of action should occur. This report will then be available to the program manager for his coordination decisions and incorporation into the comprehensive report.

The effort of writing the report as determined by both PG\&E and DWR will require approximately half a man-month. This translates to dollars as : PG\&E, $\$ 4,862$; DWR, $\$ 2,326$ for a total of $\$ 7,188$ as of December, 1980 .

LLNL was not planning to charge for the report writing. We have been involved since the inception of the Task Force as an interested and independent party with our own funding sources. Though these sources have since evaporated, it is still to our mutual benefit to continue participating in the Task Force toward parallel and/or common goals concerning the aquatic ecology in The Geysers KGRA. Without funding, however, the level of our committment is uncertain at this time. 
Responsibility

I. Field sample collection - DWR

II. Lab analysis - PG\&E

III. Data storage and analysis - PG\&E

IV. Report writing -

DWR, PG\&E, LLNL

Individual Total

Year Total

Two-Year Total $\underline{\text { Cost }}$

$\underline{\text { DWR }} \stackrel{\text { lst Year }}{\text { PG\&E }} \quad$ 2nd Year

$\$ 20,614$

$\$ 23,706$

$\$ 17,678$

$\$ 20,330$

$$
1,000
$$

1,150

\begin{tabular}{|c|c|c|c|}
\hline 2,326 & 4,862 & 2,675 & 5,591 \\
\hline$\$ 22,940$ & $\$ 23,540$ & $\$ 26,381$ & $\$ 27,071$ \\
\hline \multicolumn{2}{|c|}{$\$ 46,480$} & \multicolumn{2}{|c|}{$\$ 53,542$} \\
\hline
\end{tabular}

$\$ 96,022$

NOTE:

1. First year costs are estimates offered in December, 1980. Since this program may not get underway until Fal1, 1981, it would not be unreasonable to assume that all costs would increase $15 \%$ for the first year and subsequent years.

2. Second year figures are in fact merely $115 \%$ of first year figures.

3. This should be negotiable and left to the agency and the program manager.

For questions regarding this report, contact:

$\begin{array}{ll}\text { Robert Ireland - Chairman, LLNL } & 415 / 422-0908 \\ \text { Gerald Boles - DWR } & 916 / 527-6530 \\ \text { David Longanecker - PG\&E } & 415 / 820-2000 \\ \text { Marc Sazaki - CEC } & 916 / 920-7528\end{array}$


Acknowledgements

I would like to thank everyone involved with the committee for their ideas and eriergy, especially Gerald Boles, Dave Logananecker and Mark Sazaki. Special thanks to PG\&E for the use of their figures and drawings. 


\section{Appendix 1 .}

Background of the KGRA-ARM Task Force 
Appendix 1. Background of the KGRA-ARM Task Force

(Excerpt from KGRA-ARY Review Draft, Sept. 11, 1980)

In August 1979, representatives of the Calffornia Energy Commission (CEC), North Coast Reglonal Water Quality Control Board (NCRiQCB), Calffornia Department of Fisi and Game (COFSG), Paciflc Gas and Electric Company (PGandE), and Union 011 Company of Calliornia began a series of meetings to investigate the many, varied and largely uncoordinated aquatic resource nonitoring programs in the GeysersCalistoga KGRA and to determine whether a couprehensive, cooperative program could be developed which would be more efficient and cost effective. .

After the task force memberst concluded that a better monftoring program could be developed, it prepared a "Statement of Purpose" for distribution to the managenent of those organizations represented by the task force. The statement sumarized the problems leading to the eifort to loprove monitoring, outlined the objectives of a more comprehensive approach, and began to establish the foundation of a water quality and aquatic biology monitoring program. The manazement generally concurred with the princlples in the statement.

The task force then established four technical subconmittees to develop detailed programs in four disciplines: water quality, fisheries, benthic invertebrates, and sedimentation. The task force believed that these four aras would be the ores most likely afiected by developjent and the ores from which data could be used to analyze impacts.

*The group, collectively known as The Geysers-Callstoga KGRA Aquat1c Resources Yonitoring Task Force or KGRA-ARM Task Eorce, now also includes the Central Valley Reg1onal Water Qual1ty Control Boazd (CVRiQCB), Calffornla Department of Water Resources (DNR), U.S. Geological Survey (USGS), U.S. Bureau of Land Management (USBLY), G.R.I.P.S. Conalssion, Lairence Livermore Laboratory (ILL), Sacramento Yunicipal Ut:11ty Dist:1ct (SMID), Northern California Power Agency (NCPA), and Aminoil USA. 
The sections which follow are a compilation of programs developed by the subccarittees. For each program, the sampling and analysis techniques are specified, representative sampling stations are established, and the cost of sampling and analysis is estimaced. While the speciric programs are considered reasonable ones to study impacts from development in the KGRA in light of liaited resources, they are subject to combent and revision. The final program will take into account any cossents by parties interested in monitoring the KGRA and the personnel and funding available to implement the program.

\section{Objectives}

As identified in the Task Force's "Statement of Purpose," the objectives of this monitoring progran are:

- To evaluate cumulative inpacts on aquatic resources due to full-field geotheral development, as well as other types of development in the study area.

- To evaluate the effectiveness of measures used to protect aquatic resources frow the impacts of developing geothermal power plants, steam fields, and roads in the study area.

- To coordinate ongoing and proposed monitoring programs in The GeysersCaiistoga kCat in order to reduce redundancy, to reduce unnecessary financial and personnel eapenditures, and to promote flow of infomation anong interested agencies and persons in The Geysers-Calistoga kGR.

In addition, the results of the monitoring program are expected to expedite the regulatory process by providing information that clarifies sone of the 
uncersint: regarding the impacts of geotheral development on aquatic resources and $\vdots \because$ proyiding a standardized monitoring progran to be used in steamfield and poier plant peraics.

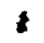




\section{Appendix 2.}

Sediment Sampling Sites and Rationale 
Appendix 2. Sediment sampling sites and rationale

Numbering of sampling sites proceed upstream from a chosen point within the watershed. For now, this is merely arbitrary convenience but, in the future, all sites will be labeled by PG\&E with the exact mileage from that chosen point in order to specifically define that sampling location (for example, BSC 10.3 means 10.3 miles upstream from the point)

Many sites have been chosen to correspond with the other committees' (water quality, fisheries, benthic) stations in order to facilitate both the sampling endeavor and the data homogeniety. This is noted in brackets beneath the sampling site descriptions and on the figures $(B=$ benthic invertebrates, $F=$ fisheries, $S=$ sediment, $W$ =water quality).

BIG SULPHUR CREEK DRAINAGE

This numbering system starts at the confluence of Big Sulphur Creek (BSC) with the Russian River.

A total of twenty(20) sites are located in the BSC drainage. Refer to Figure IA for further explanation.

Site Rationale

Big Sulphur This is the farthest downstream site and will serve as Creek: the ultimate integrator of the BSC drainage prior to the BSC 1 Russian River confluence. Additionally, this will double as a convenient reference point since a PG\&E gauging station is located here which continually monitors and records flow and total suspended solids (TSS) in the water column. 
BSC 2

BSC 3

BSC 4

BSC 5

BSC 6 (BSW)

BSC 7

BSC 8

Approximately one mile below the confluence of Little

Sulphur (LSC) Creek. Chosen to assess the mixing of LSC and BSC. Also a prior LLNL sampling site with good accessibility.

Located just below Squaw Creek (SQC). Isolates the contribution of SQC to BSC prior to input for LSC. Good accessibility.

Prior to the input from $S Q C$, this site represents the lower end of the geothermally active area and also reflects any input from the many outcroppings of abandoned mercury mines which line the upstream canyon. A previous LLNL sation with reasonable seasonal access. This site is immediately after the main cluster of active geothermal power units. The difference between BS 4 and BS 5 will reflect the degree of settling out downstream. Also a previous LLNL station.

Immediately prior to the main cluster of units and the bridge across BSC. The difference between BS 5 and BS 6 will detect input from these sources. A prior LLNL station.

This site is chosen for several reasons: one; it is immediately below the Unit 14 tributary; two, it reflects input from Hot Springs Creek (HSC), a natural geothermal tributary; three, this site corresponds to an existing PG\&E sediment sampling station. Immediate above HSC and Unit 14 tributary but below the bridge crossing BSC. The difference between BS 7 and BS 8 will isolate these two inputs. 
BSC 9

(BSW)

BSC 10

BSC 11

(BFSW)

BSC 12

(BFSW)

Little Sulphur Creek:

LSC 1
Situated upstream from the bridge. The difference between BS 8 and BS 9 will detect erosional influences from this crossing. Easy access. This site is immediately downstream from the confluence of Little Geysers Creek (LGC), a natural geothermal tributary and BSC. The site will serve as an integrater of the headwaters of BSC since often LGC will exceed the flow of BSC in this area for the last few dry months of summer. Also chosen since this corresponds to a previous LLNL site and is an area of benthic invertebrate investigation performed by the University of California, Berkeley.

Situated above LGC, this site will isolate the input from the tributary when compared to BSC 10 . The site is located below Pine Flat bridge, proposed Unit 18, the Socrates mine tributary and the Socrates mine processing area. It also corresponds to previous LLNL and PG\&E sites and is easily accessible.

This site will serve as a "clean" comparison station for the time being. In the future this site may be impacted by the NCPA 1 unit. The difference between BS 11 and BS 12 will detect inputs from those influences mentioned in site BS 11. This is a previous LLNL station. This site has been newly added to serve as a "control" station inasmuch as LSC drains a substantial area with vegetative and geologic similarity to BSC. This site will serve as background or baseline data until any future development ensues. 
Squaw Creek: Located immediately upstream from its confluence with BSC, SQC 1 this site on Squaw Creek assesses the ultimate input of (BFSW) SC to BSC.

SQC 2

This site is located just downstream from Unit 11 and the bridge crossing SQC. In comparison with site SQC3, this should measure the influence of these two sources.

SQC 3 Located above Unit 11 and the bridge, this will isolate these sources when compared with SQC2. Also serves as a cownstream station for input from Unit 17 . Corresponds to a previous PG\&E station.

$\operatorname{SQC} 4$

This site is located above Unit 17 and will be compared with SQC3. This also serves as a "clean" comparison station for all of Squaw Creek.

Cobb Creek: $\quad$ Cobb creek is a clean, spring-fed, year round spring $\mathrm{CCl}$

CC 2 originating at the ridgeline. It carves a valley between Unit 12 and Units 9 and 10 and would be subject to runoff from these sources. Located above the road and units 9 \& 10, this site should serve as a "clean" comparison station. In the future, however, this site may be affected by the proposed SMUD unit. Both CC 1 and CC 2 are prior LLNL stations. Site CC 2 has reasonable access.

Little Geysers As noted previously, LGC is a natural thermal tributary Creek: which often becomes the main headwater flow of BSC in the LGC 1 late summer. Drainage from proposed unit 18 will (BSW) probably affect LGC. It is important to assess this creek prior to its confluence with BSC because of this. This is also a previous LLNL station. 


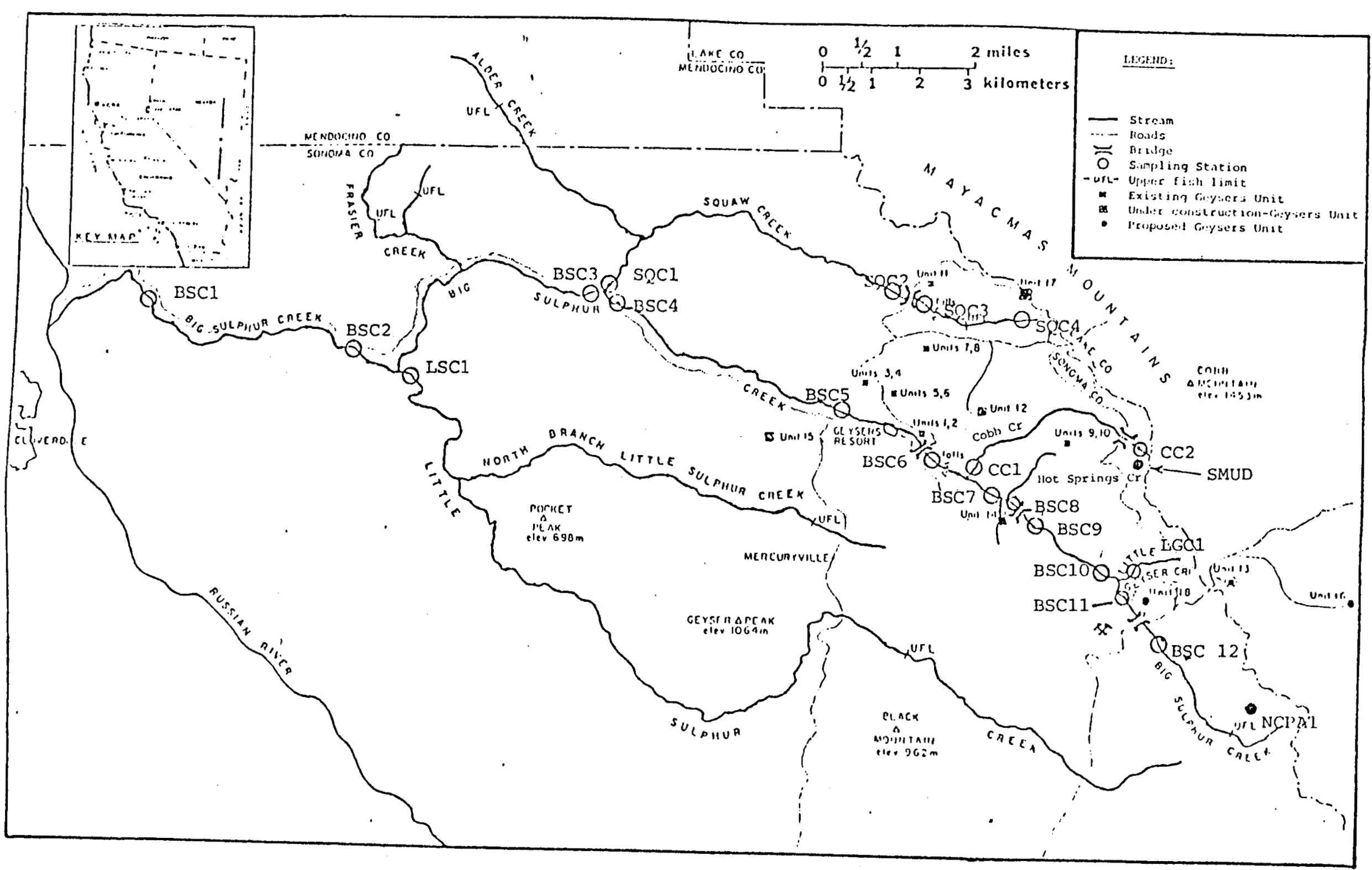

Figure 2 A Big Sulphur Creek drainage. Sediment sampling stations. 
The reference point for the future mileage numbering system will be where the bridge crosses Putah Creek downstream from the last sampling station on Putah Creek.

A total of thirteen (13) sites are located in the Upper Putah Creek (UPC) drainage.

See Figure IB for further explanation.

Site

Upper Putah

Creek:

UPC I (BS)

UPC 2

(BFSW)

\section{Rationale}

This site will be used to assess the collective input from this short but rather steep and complex network draining the UPC region. This site should serve as a "control" inasmuch as no geothermal drilling or building is occurring upstream from here. Comparison of UPC1 and UPC2 should reflect that impact to Putah Creek which is still quantifiable after input from the integrated Anderson Creek network.

Anderson Creek: Located immediately after the town of Anderson Springs, ANC 1 this site will gauge the collective input from the network of creeks prior to the town, the influence of the town itself, and that of Bear Canyon Creek and its tributaries prior to dilution in Putah Creek.

ANC 2 This site is located just prior to input from Hot Spring Creek and the town of Anderson Springs. The location should integrate Anderson Creek and Gunning Creek. This is also a prior PG\&E sediment station. 
ANC 3

$(B F S)$

ANC 4

(BSW)

$13-1$

Gunning Creek: This station is a former PG\&E sediment site located just GC 1

GC 2 (BFSW)

GC 3

Hot Spring

Creek:

H 1

This is en especially important location inasmuch as it will helo gauge the amount of erosional activity attributable to the Socrates Mine road just upstream and the tributary (tributary 13-1) originating at Unit 13. Comparison with ANC 4 will isolate these inputs. This is also a fcrrer PG\&E location.

Will serve as a "control" site for background when comparing to site ANC 3.

This tritutary evidently has no official name and has been dibted 13-1 by PG\&E because of its source. Comparison with sites ANC 3 and ANC 4 will isolate the road effects from erosional effects stemming from Unit 13. belcw the Socrates Mine road and is designed to assess that influence by comparison with site GC 2 .

As rioted above, this site will isolate the road effect. It will aiso be used to compare natural erosional activity curing the course of Gunning Creek between sites GC 2 and EC 3.

This is considered to be a "clean" site, since no man made activity is occurring above here.

This site is located just prior to its confluence with Anderson Creek. Sediment sampling here will provide data on the irout from Hot Spring Creek, a natural thermal tributary, and from the well pads upcanyon from this site. 
Bear Canyon This site is located downstream from Unit 16 and 911 the Creek: Bear Canyon Creek tributaries.

$B C C 1$

(BFSW)

$B C C 2$

This site should serve as a "clean" comparison station

(BSW)

for Bear Canyon Creek. Comparison of BCC 1 and BCC 2 should isolate erosional inputs due to unit 16 activities. 


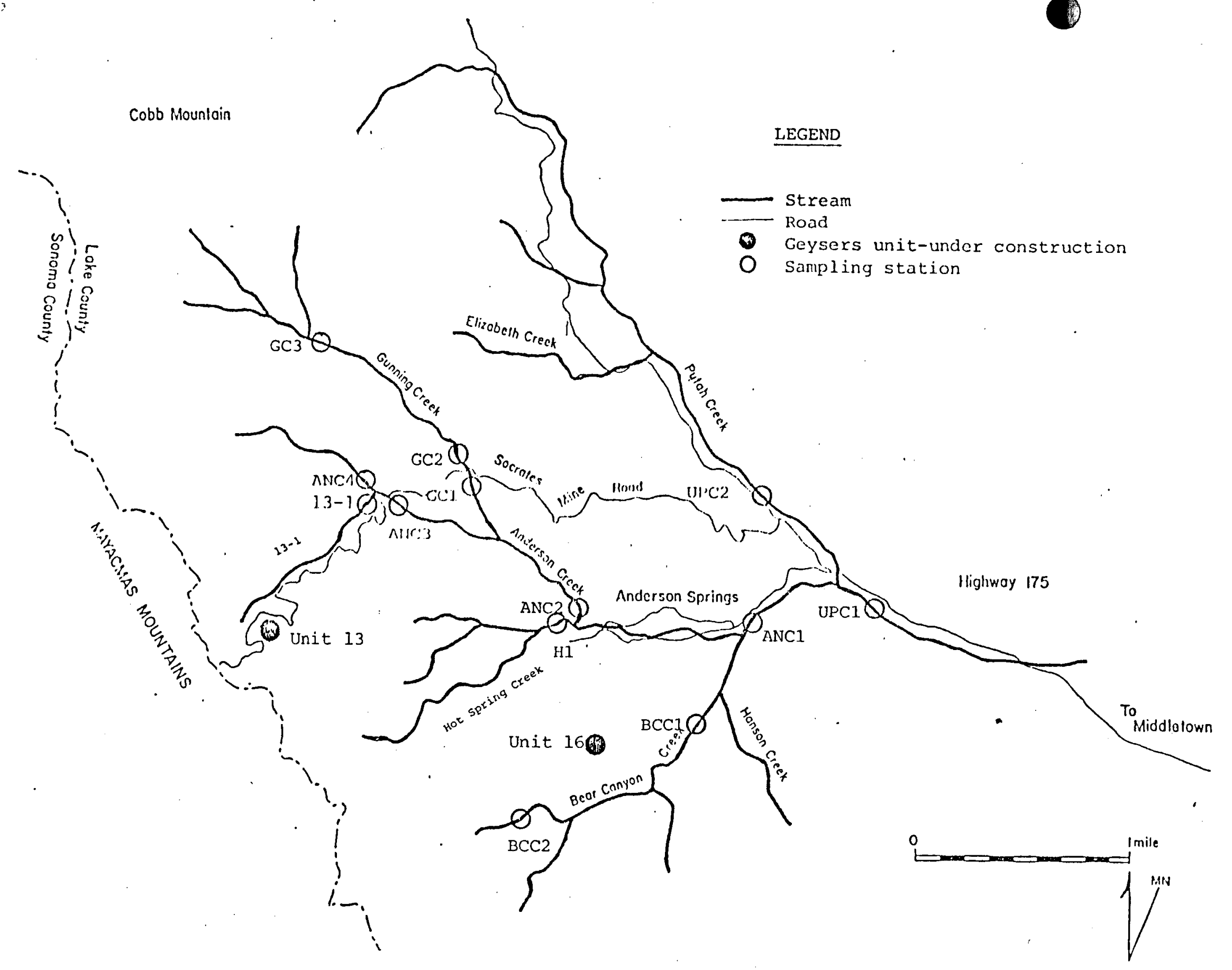

Figure 2 B Uppex Putah Creek drainage. Sediment sampling stations. 
The reference point for the future mileage numbering system will ult imately be where Kelsy Creek enters Clear Lake.

See Figure IC for further explanation.

A total of eight ( 8 ) sites are located in the Kelsey Creek (KC) drainage.

Site Rationale

Kelsey Creek: This site represents the last station in the geothermal

KC 1 development impact area. It will serve as a gauge of the (BFSW) integrated erosional activites from upper Kelsey Creek, High Valley Creek (HVC), Alder Creek (ALD) and Sulphur Creek (SUL).

KC 2 This site is located just prior to the confluence of HVC (BFSW) 1 and KC. Comparison of $K C 1$ and $K C 2$ should assess that input due to HVC. Also, this site serves as a downstream marker for siltation possibly generated from NCPA-Shell.

KC 3 Site KC 3 is a very multipurpose station. One, it serves (BSF) as the upstream site for isolation of any input from the proposed NCPA-Shell Unit. Comparison of KC 2 and KC 3 should assess this. Secondly, this site is a downstream location following possible influences from Sulphur Creek (SUL), Alder Creek (ALD), and Bottle Rock Road.

KC 4 Comparison of site KC 4 with KC 3 should detect any (BSW) differences stemming from those sources mentioned above. KC 4 by itself will detect whether the upstream towns of Cobb, Forest Lake and Whispering Pines are significantly adding any sedimentation input. 
Hich Valley This site should serve as a gauge of any erosional

Creek: $\quad$ activities which are still present and quantifiable after

HVC 1 running the course of HVC. This will be done by comparison

(BFSW) with previous data from this site and with site HVC 2.

HVC 2 This site will be located immediately below the drainage

(BS) tributary emanating from the proposed DWR-Bottle Rock

unit. This will enable one to determine whether erosional

activities are increasing due to this development, and by

comparison with HVC 1 whether these inputs are still

quantifiable downstream. Good accessibility.

Alder Creek: This site will assess the collective input from Alder and

ALD 1 Lee Creeks just prior to entering Kelsey Creek. Data

(BSi) substraction of ALD 1 from the difference of KC 3 and KC 4

will also allow us to more accurately assess the influences of Bottle Rock Road.

ALD 2 This site is located just past the confluence of Alder and Lee Creeks. The road from Geyser Rock to Bottle Rock Road may be a source of siltation as well as some current upstream well pads and will be noticed at this station. Comparison of ALD 1 and ALD 2 will allow us to gauge whether upstream sources are still significant prior to entering Kelsey Creek. 


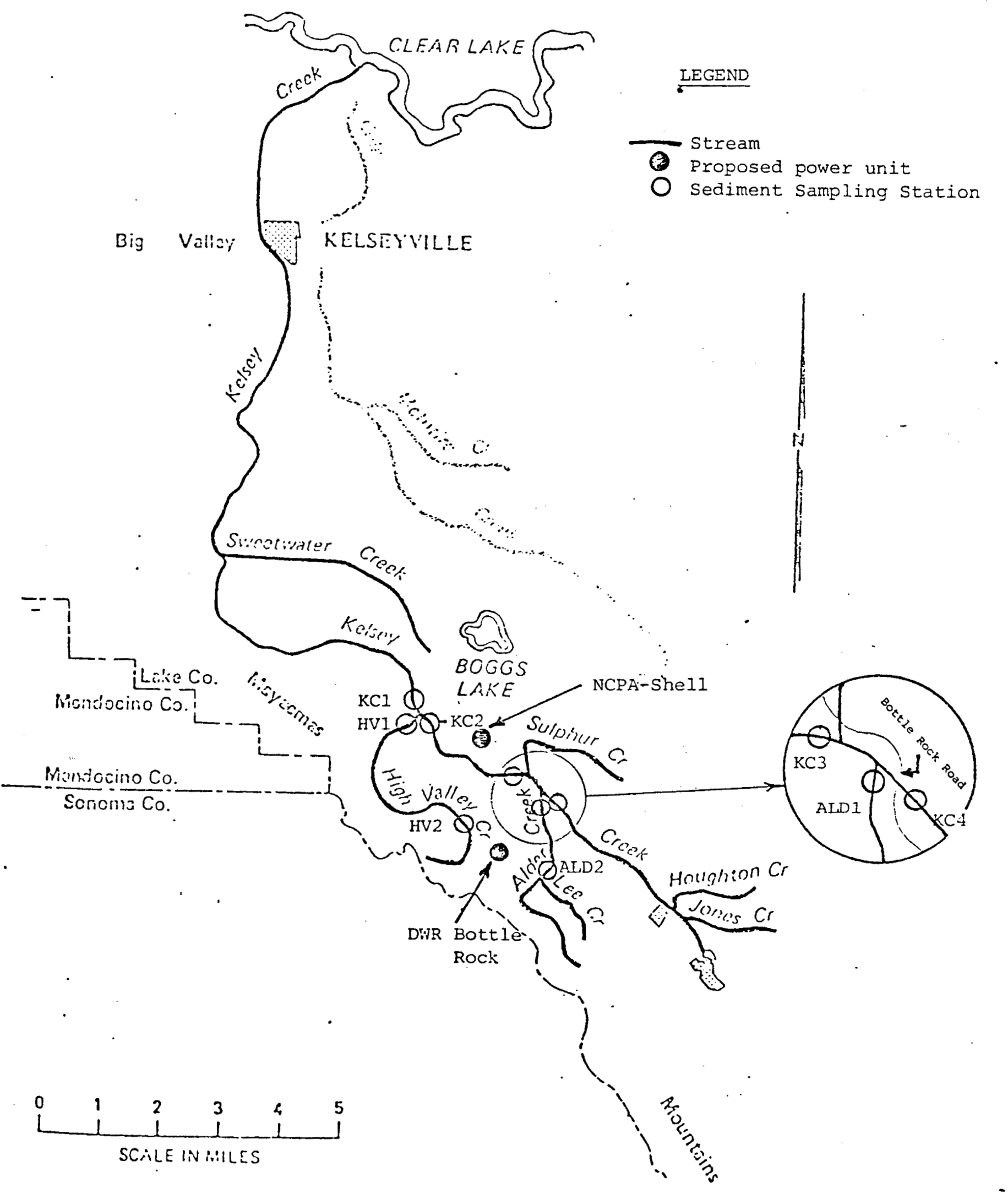

Figure 2C Kelsey Creek drainage. Sediment sampling locations. 
Appendix 3.

Directions for Testing Geysers Sediment Samples 
Appendix 3. Directions for Testing Geysers Sediment Samples

1. Set out (5) cubitainers containing fines, and allow to settle undisturbed for approx. 4 hours.

2. Empty (5) bulk samples from sample bags into tared pans. Wash all sample clinging to bag into pan. Place bulk samples in oven to dry overnight.

3. Siphon supernatant from each settled cubitainer into graduated cylinder. Measure and record volume of sample removed before discarding. Be careful not to siphon any of the settled sludge, or stir up the sample.

4. Measure and record remaining slurry and empty into tared pan. Be sure to wash out all of the sludge into the pan. Carefully place pan in oven to dry overnight. Repeat for each sample.

5. Remove bulk samples from oven and allow to cool until luke warm. Record weights of each sample. Do not leave samples out for extended periods (more than 2 hours), as they will absorb water from the air.

6. Split bulksample over a large No. 4 screen by hand. Record weight of the $<$ No. 4 and > No. 4 portions of sample.

7. For sample portion > No. 4, sieve manually (shake by hand, helping the rocks through the sieves) through $3^{\prime \prime}, 11 / 2^{\prime \prime}, 3 / 4^{\prime \prime}, 1 / 2 ", 3 / 8^{\prime \prime}$, and No. 4 sieves. Record weight of material on each sieve. Check subtotal with known subtotal before discarding this portion of bulk sample. Repeat if large error exists.

8. For portion of sample < No. 4, mechanically shake sample for 10-15 minutes through No. 5T, No. 8 , No. 16 , No. $20 \&$ No. 30 sieves. Record weights on each sieve, as well as sample portion passing No. 30 sieve. Check subtotal before discarding > No. 30 portion of sample. Retain < No. 30 portion. 
9. Remove fines sample from oven and allow to cool until lukewarm. Record weight of sample. Scrape sample into mortar and pestal and carefully pulverize sample as completely as possible.

10. Check field data for volume of fines sample discarded in the field. Perform the following equation to determine sample ratio:

$$
\begin{aligned}
& \text { Volume of fines sample in cubitainer } \\
& \text { Volume of fines sample in cubitainer } t \\
& \text { volume discarded in field }
\end{aligned}
$$

11. Multiply < No. 30 portion of bulk sample by sample ratio. Mechanically split bulk sample until you have this weight.

12. Combine pulverized fines sample with the proportioned < No. 30 bulk sample, and mechanically sieve over No. 20, No. 30, No. 50, No. 100, No. $150 \mathrm{~T}$, and No. 200 sieves.

Record each weight, including the pan. Check subtotal weight before discarding entire sample. 
FINE SAMPLE

Tare No.

1. (a) Dry wt. of fines sample and tare

(b) Tare wt.

(c) Dry wt. of fine samp le

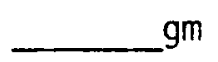

gm

gm

II. (a) Volume of water and fines in cubitainer $\mathrm{ml}$

(b) Volume of water and fines discarded in sampling ml

(c) Sample ratio

$$
\frac{(a)}{(a)+(b)}=
$$

\begin{tabular}{ll}
$\begin{array}{l}\text { Sieve } \\
\text { Size }\end{array}$ & $\begin{array}{c}\text { Weight } \\
\text { Retained } \\
\text { (gm) }\end{array}$ \\
\hline $3 "$ & \\
$1-1 / 2^{\prime \prime}$ & \\
$3 / 4^{\prime \prime}$ & \\
$1 / 2 "$ & \\
$3 / 8 "$ & \\
No. 4 & \\
$5 T$ & \\
8 & \\
16 & \\
20 & \\
30 & \\
Subtotal & \\
\hline No. 50 & \\
100 & \\
$150 T$ & \\
200 & \\
\hline & \\
\hline
\end{tabular}

BULK SAMPLE

Tare No.

III. (a) Dry wt. of bulk sample and
(b) Tare wt.
(c) Dry wt. of bulk sample

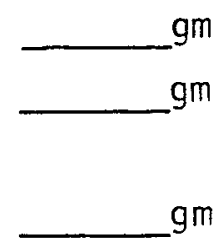

IV. (a) Dry wt. of bulk sample passing the No. 30 sieve

(b) Dry wt. of bulk sample not passing the No. 30 sieve gm

(c) Bulk ratio wt.

$$
\text { (IIc } \times \text { IVa) }
$$

gm

(d) Total ratio wt.

$$
(I c+I V c)
$$

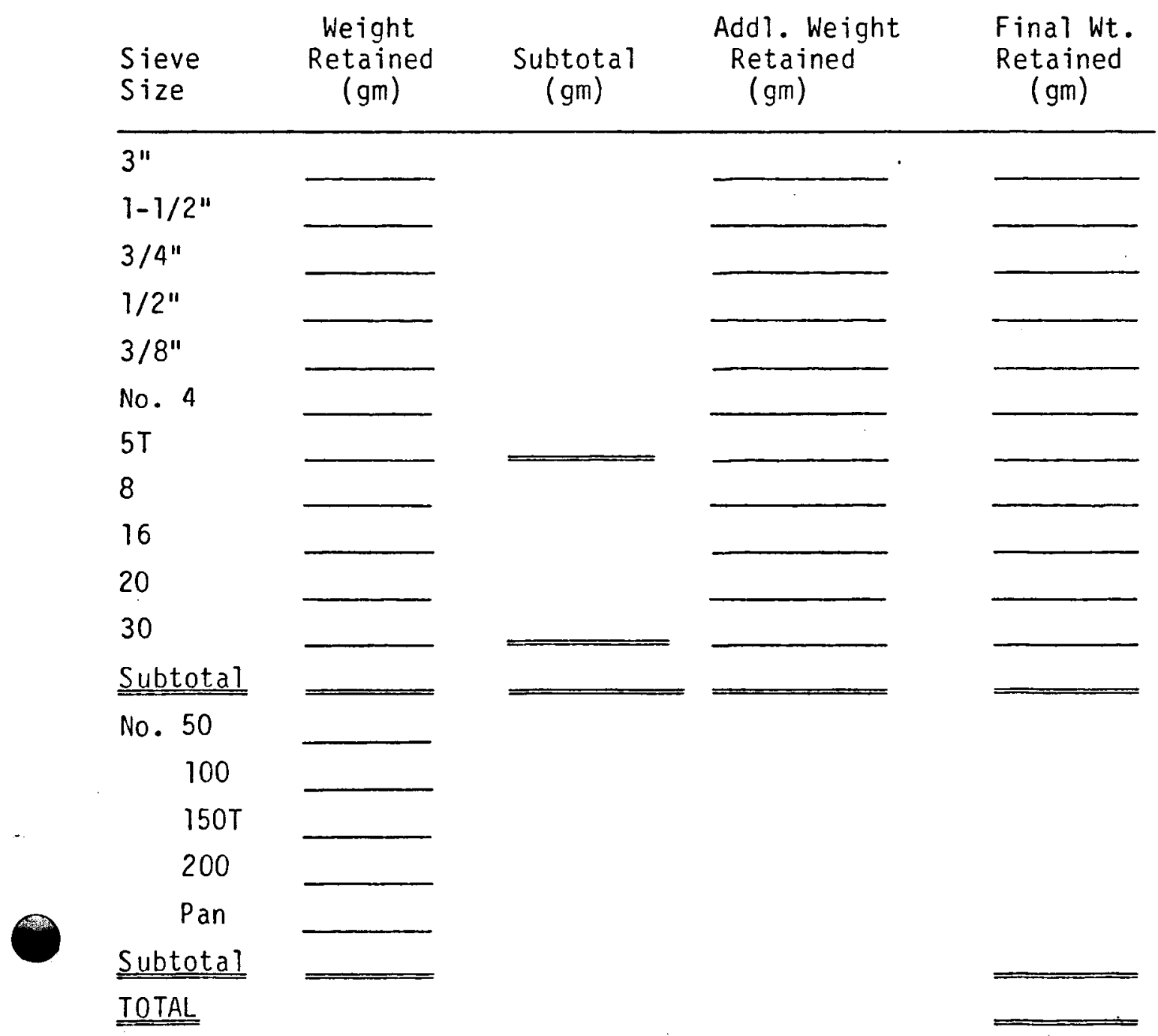




\section{Appendix 4.}

Examples of Computer Generated Graphic Displays and Tabular Output 
Appendix 4: Examples of computer generated graphic displays and tabular output.

PG\&E currently has the expertise for computerized sediment data reduction. Computer programs were developed to analyze the particle size data and to produce several types of printouts. Figures $3 A-F$ were copied with permission from PG\&E Report 420-80.94. 1980.

Fig. 4 A. Sediment Analysis, General Statistics for Unit...

This printout provides the percent weight retained of each particle size for the five replicates sampled at a station on a particular sampling date. ("Mean diameter" refers to the midpoint of the range of particle sizes that would be retained on the corresponding sieve, having passed through the next largest sieve. "Percent difference" is a check for correct transcription of the data.)

Fig. 4 B. Summary of Grain Size Analys is for Geysers Unit...

This printout provides the mean percent weight of the particles passing each sieve size for each station on a particular sampling date. ("Diameter" refers to the mesh sizes of the sieves.) 
Fig. 4 C. Grain Size Distribution...

This printout provides a chart of the grain size distribution for a station on a particular sampling date. (The numbers along the abscissa (76.2, 38.1 . . 0.074) refer to mesh sizes of the sieves used in the anaiysis. A point on the curve above a particular mesh size represents the percentage, by weight, of particles in a sample that passed through that sieve.)

Fig. 4 D. Bar Chart of Geomean

This printout provides a graphical comparison of several sampling stations before during, and if available, after construction. The geomean is the average particle size. If the geomean becomes smaller, then the average particle size has decreased indicating erosion and sedimentation processes.

Fig. 4 E. Block Chart of Percentage Fines

This printout provides a visual comparison of the seasonal variations of the percentage of $f$ ines and their relationship to the phase of construction. The percentage fines is determined by dividing the weight of the fines (most often considered as $\leq 0.84 \mathrm{~mm}$ ) by the total weight of the sample. This example seems to indicate that the percentage generally increased after construction began. 
SEDIMENT AIIALYSIS CEMERAL STMTISTICS FOR

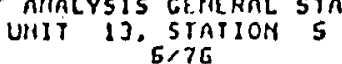

\begin{tabular}{|c|c|}
\hline SIEUE SIZE & REAII DINRETER (nn) \\
\hline $3,111$. & 108.608 \\
\hline $1 / 2$ IN. & 57.140 \\
\hline 3/1 וк. & 28.580 \\
\hline $1 / 2 I M$. & 15.800 \\
\hline $3 / 8 \mathrm{IH}$. & 11.109 \\
\hline 10. 4 & 7.139 \\
\hline 110. $5 \mathrm{~T}$ & 4.059 \\
\hline 110.8 & 2.858 \\
\hline NO. 16 & .1 .771 \\
\hline 110. 20 & 1.014 \\
\hline ко. 33 & .714 \\
\hline No. 50. & .413 \\
\hline 110.100 & .222 \\
\hline HO. $150 T$ & .126 \\
\hline $110.2 \mathrm{co}$ & .088 \\
\hline PAll. & \\
\hline TOTAL & \\
\hline
\end{tabular}

\begin{tabular}{|c|c|c|c|c|}
\hline & CENT & 17 & TA & \\
\hline & - & -6 & D & \\
\hline $0.0^{\circ}$ & 0.0 & 0.0 & 0.0 & \\
\hline 8.9 & 0.0 & 0.0 & 7.8 & \\
\hline 21.2 & 0.0 & 1.2 & 10.9 & \\
\hline 8.2 & 1.9 & 13.6 & 12.7 & \\
\hline 8.8 & 7.2 & 16.1 & 8.2 & \\
\hline 12.8 & 33.5 & 33.2 & 15.7 & \\
\hline 2.7 & 7.8 & 6.5 & 2.7 & \\
\hline 0.3 & 23.4 & 14.5 & 9.1 & \\
\hline 11.5 & 14.3 & 6.3 & 10.0 & \\
\hline 1.1 & 2.6 & 1.0 & 3.3 & \\
\hline 3.5 & 1.8 & 0.6 & 2.8 & \\
\hline 3.2 & 1.7 & 0.5 & 2.8 & \\
\hline 1.7 & 1.1 & 0.4 & 1.1 & \\
\hline 0.6 & 0.6 & 0.2 & 0.5 & \\
\hline 0.3 & 0.3 & 0.1 & 0.2 & \\
\hline 3.1 & 2.3 & 2.1 & 2.1 & \\
\hline
\end{tabular}

$S T .0$
$0 E U$.
0.0
0.4
5.0
5.1
0.6
2.5
6.0
3.5
1.2
1.2
1.1
0.
0.
0.2
0.6

$100.0100 .0100 .0100 .0 \quad 99.8$

DIFTCREMCE

SUN OF FUR $1-1 B$
ADJUSTED TOTAL UEJOHT

PERCEHT DIFFERENCE

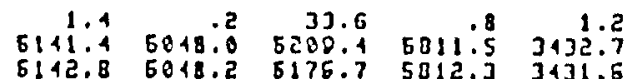

$\begin{array}{llll}.02 & .85 & .01 & .03\end{array}$

Figure 4 A. 

SUMARAY OF ORNIN SIZE AIIALYSIS FOR CEYSERS UHIT 13 SEOIMENT GTUUY
FOR TME S/76 PERIOD PERCEIT PASBIIIO QY UEIGHT 2

\begin{tabular}{|c|c|}
\hline SIEUE SIZE & DIAMETER (NM) \\
\hline $3 \mathrm{III}$. & 76.100 \\
\hline 112111. & 38.020 \\
\hline $3 / 4 \mathrm{IH}$. & 10.020 \\
\hline $1 / 2111$. & $\$ 2.699$ \\
\hline $3.8 \mathrm{lll}$. & 9.510 \\
\hline 110.4 & 4.750 \\
\hline $110.5 \mathrm{~T}$ & 3.350 \\
\hline 110.8 & 2.350 \\
\hline 110. is & 1.189 \\
\hline 110.20 & .839 \\
\hline 110.30 & .589 \\
\hline 110.50 & .296 \\
\hline 140.100 & .148 \\
\hline 110.1507 & .103 \\
\hline NO. 200 & .073 \\
\hline
\end{tabular}

\begin{tabular}{|c|c|c|c|c|c|}
\hline $\begin{array}{l}\text { STATION } \\
\text { MEAII }\end{array}$ & CEU & $\begin{array}{l}\text { SInTION } \\
\text { MEMBI }\end{array}$ & $\begin{array}{c}6 \\
\text { LEV }\end{array}$ & $\begin{array}{l}\text { STATlOA } \\
\text { menil }\end{array}$ & $\begin{array}{c}7 \\
0 E v\end{array}$ \\
\hline 100.0 & 0.0 & 07.5 & 6.6 & 92.5 & 10.3 \\
\hline 86.6 & 4.6 & 80.1 & 8.6 & 79.7 & 15.0 \\
\hline 83.0 & 13.3 & 70.0 & 3.6 & 50.0 & 13.4 \\
\hline 73.1 & 16.1 & 50.9 & 5.2 & 48.2 & 10.6 \\
\hline 61.6 & 17.2. & 52.1 & 6.5 & 30.7 & 8.4 \\
\hline 37.8 & 11.8 & 37.0 & 7.2 & 24.8 & 5.6 \\
\hline 33.1 & 10.5 & 35.2 & 7.0 & 22.2 & 6.2 \\
\hline 20.6 & 7.2 & 26.1 & 6.1 & 14.0 & 4.8 \\
\hline 10.0 & 4.5 & 16.4 & 1.2 & 7.0 & 3.8 \\
\hline 8.4 & 3.3 & 12.7 & 2.9 & 5.0 & 2.2 \\
\hline 6.3 & 2.1 & 9.2 & 1.6 & 3.4 & 1.6 \\
\hline 1.3 & 1.1 & 5.5 & 0.6 & 1.0 & 0.8 \\
\hline 3.1 & 0.6 & 3.7 & 0.3 & 1.3 & .0 .6 \\
\hline 2.6 & 0.5 & 3.2 & 0.2 & 1.1 & 0.5 \\
\hline 2.1 & 0.5 & 2.8 & 0.2 & 1.0 & 0.5 \\
\hline-0.0 & 0.0 & -0.0 & 0.0 & -0.0 & 0.0 \\
\hline
\end{tabular}

- SIEUE SIZES ARE U.S. STMHDRRD SIEUE SIZES EXCEPT WHERE

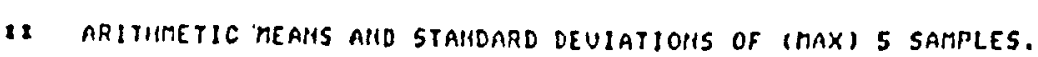




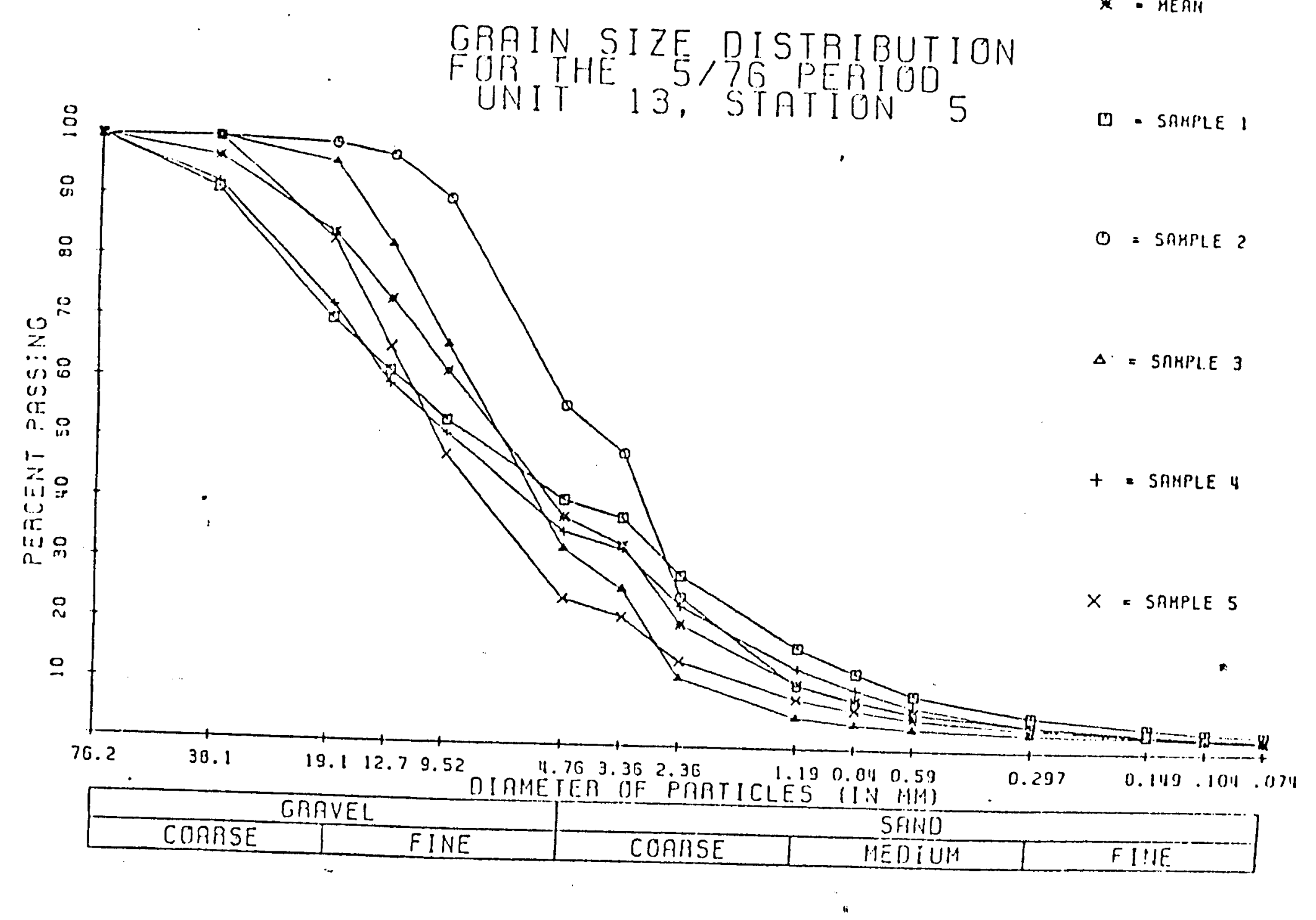

Figure $4 \mathrm{C}$ 
I ASOSN SPRINC UNIT:=13

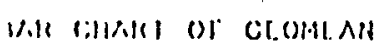

: LOMCAN

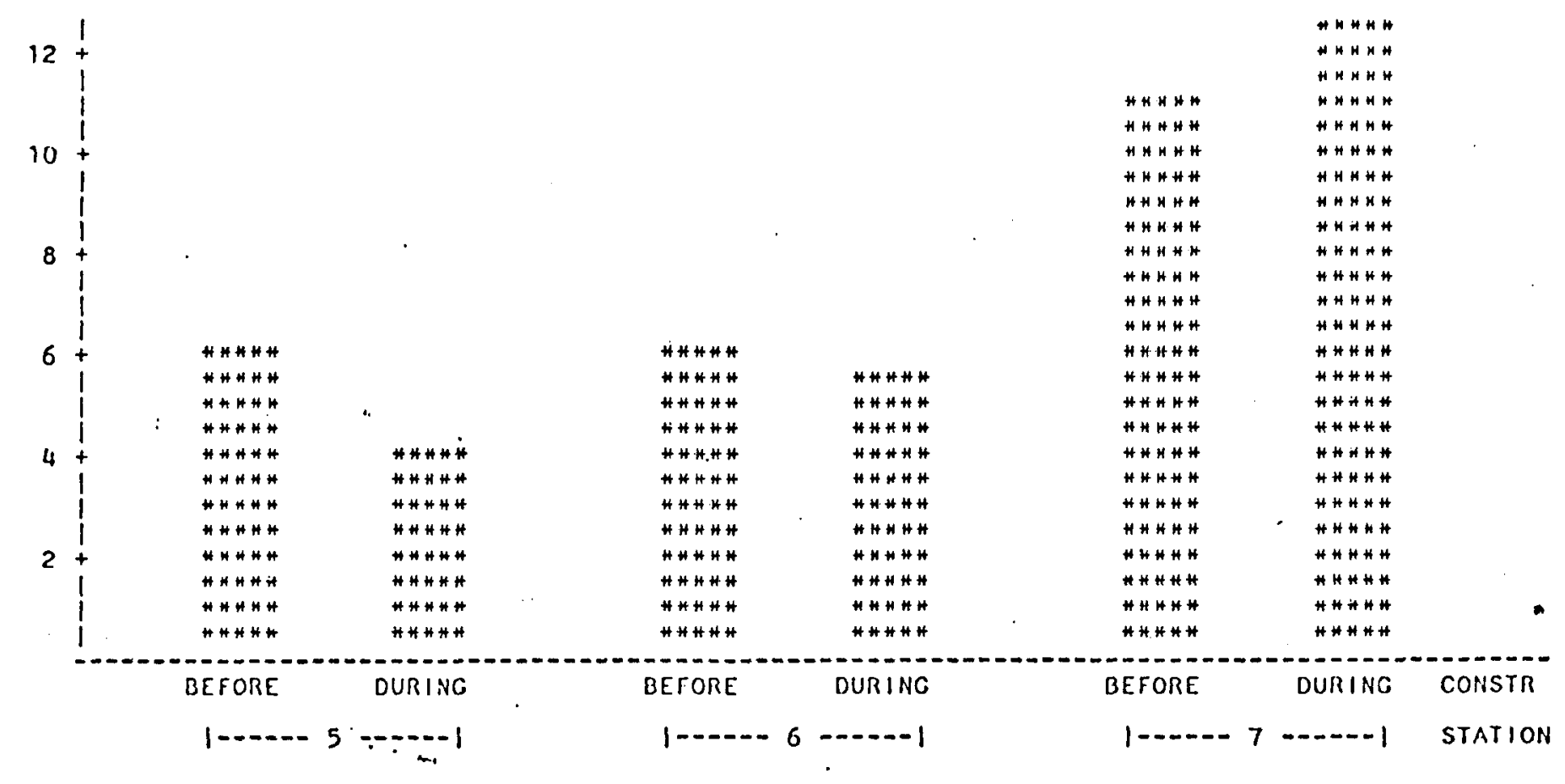

Figure 4 D 


\section{ITAT 10:i=5}

BLOCK CHART OF PCTFIIIES

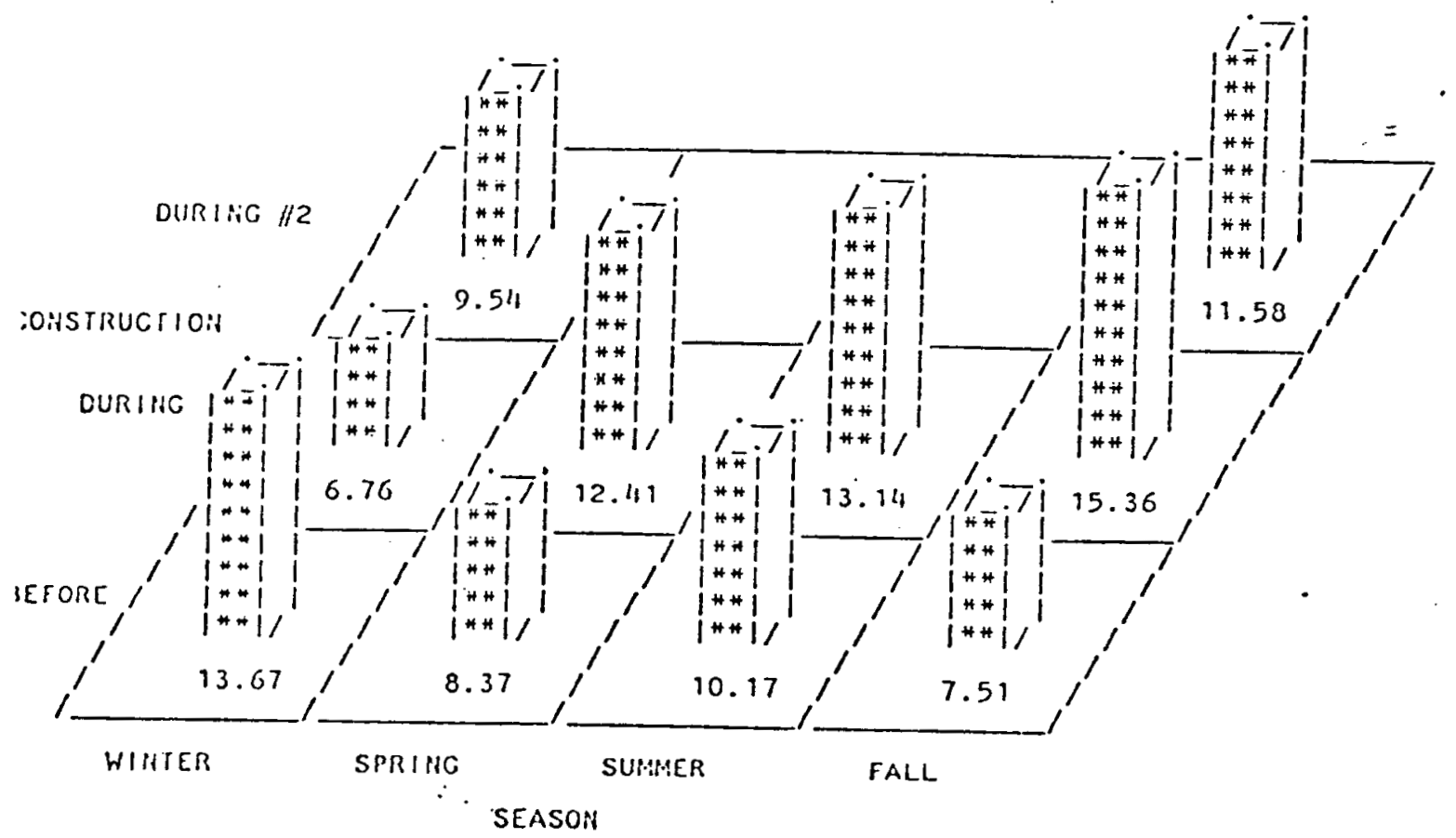

Figure 4 E 


\section{DISCLAIMER}

This document was prepared as an account of work sponsored by an agency of the United States Government. Neither the United States Government nor the Liniversity of California nor any of their employees, makes any warranty, express or implied, or assumes any legal liability or responsibility for the accuracy, completeness, or usefulness of any information, apparatus, product, or process disclosed, or represents that its use would not infringe privately owned rights. Reference herein to any specific commercial products, process, or service by trade name, trademark, manufacturer, or otherwise, does not necessarily constitute or imply its endorsement, recommendation, or favoring by the Linited States Government or the University of California. The views and opinions of authors expressed herein do not necessarily state or reflect those of the United States Government thereof, and shall not he used for advertising or product endorsement purposes.

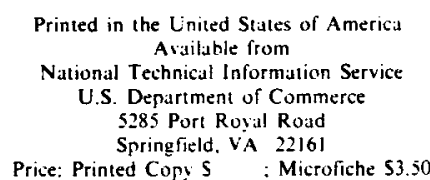

\begin{tabular}{|c|c|c|c|}
\hline Page Range & $\begin{array}{l}\text { Domestic } \\
\text { Price }\end{array}$ & Page Range & $\begin{array}{l}\text { Domestic } \\
\text { Price }\end{array}$ \\
\hline $001-025$ & $\$ 5.00$ & $326-350$ & $\$ 18.00$ \\
\hline $026-050$ & 6.00 & $351-375$ & 19.00 \\
\hline $051-075$ & 7.00 & $376-400$ & 20.00 \\
\hline $076-100$ & 8.00 & $401-425$ & 21.00 \\
\hline $101-125$ & 9.00 & $426-450$ & 22.00 \\
\hline $126-150$ & 10.00 & $451-475$ & 23.00 \\
\hline $151-175$ & 11.00 & $476-500$ & 24.00 \\
\hline $176-200$ & 12.00 & $501-525$ & 25.00 \\
\hline $201-225$ & 13.00 & $526-550$ & 26.00 \\
\hline $226-250$ & 14.00 & $551-525$ & 27.00 \\
\hline $251-275$ & 15.00 & $526-550$ & 28.00 \\
\hline $276-300$ & 16.00 & 601 -up 1 & \\
\hline $301-325$ & 17.00 & & \\
\hline
\end{tabular}

1 Add 2.00 for each additional 25 page increment from 601 pages up. 